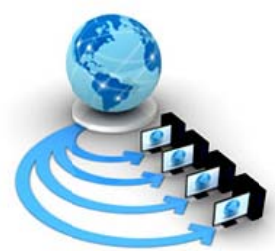

Volume 9, No. 1, January-February 2018

International Journal of Advanced Research in Computer Science

RESEARCH PAPER

\title{
DECISION SUPPORT SYSTEM FOR SMART FARMING WITH HYDROPONIC STYLE
}

\author{
Anuradha Thakare \\ Department of Computer Engineering \\ PCET's Pimpri Chinchwad College of Engineering \\ Pune, India \\ Payal Budhe \\ Department of Computer Engineering \\ PCET's Pimpri Chinchwad College of Engineering \\ Pune, India
}

\author{
Priyanka Belhekar \\ Department of Computer Engineering \\ PCET's Pimpri Chinchwad College of Engineering \\ Pune, India \\ Uday Shinde \\ Department of Computer Engineering \\ PCET’s Pimpri Chinchwad College of Engineering \\ Pune, India
}

\author{
Vaishnavi Waghmode \\ Department of Computer Engineering \\ PCET's Pimpri Chinchwad College of Engineering \\ Pune, India
}

\begin{abstract}
Due to rapid industrialization, arable land is decreasing. Hydroponic farming technique includes producing fruits, flowers and vegetables especially in the areas where gardening is challenging due to unsuitable soil. Hydroponic farming facilitates soil-less gardening. In large greenhouse operations, hydroponics is used to grow various exotic crops. The smart farm can be made fully automated, log multiple sources of data and capable of wireless control.

This article suggest work-in-progress model for smart farming with hydroponic style by linking a smart sensing system and smart irrigation system through wireless communication technology. The system will real-time monitor the temperature, humidity changes, moisture content, nutrient content, $\mathrm{pH}$ of the water, fine flow required and efficient use of water resources that plays a vital role in farming activities. Remote sensing humidity for farm water will be measured on the basis of continuous, multi point and accurate moisture values. A Decision Support System implemented with this approach will facilitate the farmers with remote monitoring of farms.
\end{abstract}

Keywords: Hydroponics technique; Water flow; Nutrients; Crops; Nutrient content.

\section{INTRODUCTION}

Rapid industrialization of the global economy and alarmingly increasing population compels countries like India to upgrade their agricultural techniques to meet the needs of the people. Soil less agricultural techniques like hydroponics [1] have gained a lot of importance over the years, one of the most popular soil less agricultural technique in which the crops are grown in nutrient solutions is now gradually being employed for commercial agriculture. India, in spite of being an agro based country, has found it very challenging to implement hydroponics on a commercial scale. Sensitivity of hydroponics to technical faults is a major limiting factor when it comes to their large scale implementation. In addition to this, agriculture in India is predominantly being practiced by unskilled labor which makes imparting knowledge on hydroponics even more challenging. Considering the wide range of advantages which hydroponics offer and increasing need to meet the food requirements of the growing population with the limited agricultural land available, practicing hydroponic procedures has become the need of the hour. Automation of Hydroponics is a viable concept which can solve the challenges faced in its implementation [8].
Among all the procedures involved in hydroponic process, preparation of nutrient solution is the most sensitive one hydroponic cultivation shows very little error tolerance nutrient quality. Studies have shown that the nature of nutrient solution varies randomly throughout the growth cycle of crops and it is very important to maintain its quality at optimum level to ensure high yield. Several optimization procedures have been used to optimize the process of nutrient solution control. A novel FIS grading system has been developed for this purpose based on expert guidance from agricultural scientists of Murugappa Chettiar Research Center (MCRC), Chennai, India. The designed FIS is used as fitness function to execute genetic algorithm which optimizes the control system parameters of nutrient preparing unit periodically and thus maintaining the quality of solution.

\section{RELATED RESEARCH}

Hydroponics is a technique to grow the plant without using the soil. This technique ensures the plant gets all nutrients needed from the water solution. There are many types of hydroponics technique [1]. The Deep Water Culture (DWC) is one of the hydroponics technique types. DWC is a technique that grows the plant by supplying the nutrient direct to the root of the plant until the plant can be 
harvested. By using this technique, the plant root will be always submerged into the water that contains nutrient and oxygen. However, this technique manually controlled the $\mathrm{pH}$ water, which can give bad effect to growing of plant. In this research, the $\mathrm{pH}$ level in water solution will be automatically maintained by micro-controller and measured by sensor.

Design of Efficient Hydroponic Nutrient Solution Control System using Soft Computing based Solution Grading was proposed [2] which discusses that as, the period of $\mathrm{pH}$ level started to change, the effects of $\mathrm{pH}$ adjuster solution to the water solution are determined. Lastly, this research also focuses on the ability of the system can adjust the $\mathrm{pH}$ value in water solution for DWC. The water solution from the DWC container is transferred to the main tank to measure the $\mathrm{pH}$ level by sensor and make adjustment if needed and then transfer back to the deep water culture container to continue growing the plant.

There are six stages in methodology for this project, which are details of study, hardware identification, software identification, hardware and software interfacing, analysis and troubleshooting, data and result collection [3]. The result from the experiment test showed that the system able to decrease the $\mathrm{pH}$ level by $0.58 \mathrm{pH}$ and increase the $\mathrm{pH}$ level by $1.15 \mathrm{pH}$. Hydroponics is a technique to cultivate the plant without using soil as a growth medium. This paper presents an efficient hydroponic nutrient solution control system whose system parameters are optimized using genetic algorithm.

A development of an automatic microcontroller system for Deep Water Culture (DWC)," in Signal Processing and its Applications (CSPA) discuss a novel mamdani fuzzy inference system (FIS) that grades the quality of solution for a given set of control parameters has been used as its fitness function [4]. The FIS evaluation function has been designed using expert opinion from researchers at Murugappa Chettiar Research Center, India. To evaluate the performance of the proposed algorithm, a virtual hydroponic nutrient control system with a solution monitoring unit was designed using Lab view. The designed algorithm demonstrated better convergence efficiency and resource utilization compared to conventional error function based nutrient solution control systems.

This technique supplies the nutrient needed by plant through the water solution [5]. There are many types of hydroponics technique such as deep water culture, aeroponic system, drip system, EBB and flow (food and drink) system, N.F.T (nutrient film technique) and wick system. Deep water culture (DWC) is one of the hydroponic system techniques that prepare the nutrient in water solution into the plant. This technique will ensure the root of plant will absorb the nutrient in water solution to grow wisely.

Nutrient Solution Control Network for Hydroponics System was proposed [6]. By using this technique, there are several environmental factors that should be considered such as oxygenation, salinity, $\mathrm{pH}$ and conductivity of nutrient solution, light intensity temperature, photo period and air humidity. There are two variables must be considered when growing the plant in nutrient solution, which is electrical conductivity (EC), potential of hydrogen ion $(\mathrm{pH})$.

A system for measuring the photosynthetic activity of water plants based on carbon dioxide absorption [7], states the changing of $\mathrm{pH}$ level will affect to the photosynthetic activity of plants, due to $\mathrm{CO} 2$ is readily soluble in water and decreases the $\mathrm{pH}$ the maximal growth of plant can be achieved by increasing it capacity. Since the $\mathrm{pH}$ value can give effect to the photosynthetic activity of plant, the $\mathrm{pH}$ level in water solution should be controlled to avoid the plant will be damaged. However, the DWC technique is not equipped with an automatic system that able to maintain the $\mathrm{pH}$ level in water solution, and the user need to adjust the $\mathrm{pH}$ level in water solution manually.

Hydroponic cultivation of garden tomatoes require $\mathrm{pH}$ of the nutrient solution to lie within 5.5-6.5 and EC within 2.05.0 as described by Caruthers and Jones [8]. Table 1 describes the range of $\mathrm{pH}$ values and its corresponding effect on the plant system. The Electrical conductivity of the solution is a measure of nutrient salts available in the solution. Thus maintaining EC of the solution is very important for healthy growth of the plants. Several nutrient solution control system designs have been proposed in the past two decades which primarily involve the use of sensors to invoke a genetic algorithm in case of any change in the nature of the solution and determine the alterations to be done in the nutrient concentrations to replenish its quality. Fuzzy Logic controllers (FLC) have been used in this technique to perform the control action whose membership function was altered by the genetic algorithm.

Automated indoor Aquaponic cultivation technique developed, the word 'Aquaponic' refer to the integration of 'hydroponic' (growing plant/vegetable production without soil) with aquaculture (fish farming)[9]. This research was conducted to design a system that could maintain the $\mathrm{pH}$ level in water solution for DWC system, which could decrease and increase the $\mathrm{pH}$ level in water solution automatically. In order to make the system operate automatically, a microcontroller that can control the operation is required in this system. There are many types of microcontroller can be used in this project such as PIC controller, PLC controller and Arduino microcontroller.

Portable Device for Stock Identification System (PDSIS) [10] discuss the $\mathrm{pH}$ level in water solution to the deep water culture is should be maintained to ensure the plant grows wisely. In this research, the mustard green was taken as a plant sample. The suitable range $\mathrm{pH}$ level for mustard green is 6.0 to 7.5. The nutrient is supplied to the plant by mixture the water solution with fertilizer before started to grow the plant. After that, the suitable of $\mathrm{pH}$ value of the plant must be set up first by using a keypad button that connected with the Arduino Mega 2560 microcontroller. Once, the $\mathrm{pH}$ level was entered the system will automatically make a comparison between $\mathrm{pH}$ level value in water solution with range of suitable $\mathrm{pH}$ level value.

Table I. Literature Survey

\begin{tabular}{|c|c|c|c|c|}
\hline $\begin{array}{l}\text { Sr. } \\
\text { No. }\end{array}$ & Paper Title & Published By & Advantage & Limitations \\
\hline 1 & $\begin{array}{c}\text { Automated pH } \\
\text { Controller } \\
\text { System for } \\
\text { Hydroponic } \\
\text { Cultivation }\end{array}$ & $\begin{array}{l}\text { Saaid M.F., } \\
\text { Sanuddin A., } \\
\text { Megat Ali, } \\
\text { M.S.A. I.M } \\
\text { Yasin:2015 } \\
\text { IEEE }\end{array}$ & $\begin{array}{c}\text { Covers study } \\
\text { of techniques } \\
\text { for } \\
\text { controlling } \\
\text { pH levels of } \\
\text { water. }\end{array}$ & $\begin{array}{l}\text { Works for } \\
\text { The Deep } \\
\text { Water } \\
\text { Culture } \\
\text { (DWC). }\end{array}$ \\
\hline 2 & $\begin{array}{c}\text { Design of } \\
\text { Efficient } \\
\text { Hydroponic } \\
\text { Nutrient } \\
\text { Solution } \\
\text { Control System }\end{array}$ & $\begin{array}{c}\text { Lenord Melvix } \\
\text { J.S.M, Sridevi } \\
\text { C.2014(ICCPE } \\
\text { TC). }\end{array}$ & $\begin{array}{c}\text { Fuzzy } \\
\text { inference } \\
\text { system (FIS) } \\
\text { that grades } \\
\text { the nutrient } \\
\text { solution } \\
\end{array}$ & $\begin{array}{c}\text { Efficiency is } \\
\text { less and } \\
\text { fuzzy } \\
\text { interface } \\
\text { system } \\
\text { requires }\end{array}$ \\
\hline
\end{tabular}




\begin{tabular}{|c|c|c|c|c|}
\hline & $\begin{array}{c}\text { using Soft } \\
\text { Computing } \\
\text { based Solution } \\
\text { Grading }\end{array}$ & & control. & $\begin{array}{l}\text { large set of } \\
\text { data. }\end{array}$ \\
\hline 3 & $\begin{array}{c}\text { A development } \\
\text { of an automatic } \\
\text { microcontroller } \\
\text { system for } \\
\text { Deep Water } \\
\text { Culture (DWC) }\end{array}$ & $\begin{array}{c}\text { Saaid, M.F. } \\
\text { Yahya, } \\
\text { N.A.M. ; } \\
\text { Noor, M.Z.H. ; } \\
\text { Ali, } \\
\text { M.S.A.M,2013 } \\
\text { IEEE }\end{array}$ & $\begin{array}{l}\text { Deep Water } \\
\text { Culture } \\
\text { (DWC) } \\
\text { isused for } \\
\text { cultivation }\end{array}$ & $\begin{array}{c}\text { Nutrient } \\
\text { Film } \\
\text { Technique } \\
\text { (NFT) can't } \\
\text { be obtained } \\
\text { i.e. } \\
\text { remaining } \\
\text { hydroponic } \\
\text { styles cannot } \\
\text { be } \\
\text { implemented }\end{array}$ \\
\hline 4 & $\begin{array}{l}\text { A system for } \\
\text { measuring the } \\
\text { photosynthetic } \\
\text { activity of } \\
\text { water plants } \\
\text { based on } \\
\text { carbon dioxide } \\
\text { absorption }\end{array}$ & $\begin{array}{l}\text { Nakaoka and } \\
\text { A. Yamada, in } \\
\text { Micro- } \\
\text { NanoMechatro } \\
\text { nics and } \\
\text { Human } \\
\text { Science } \\
\text { (MHS), } 2012\end{array}$ & $\begin{array}{c}\mathrm{An} \\
\text { automated } \\
\mathrm{pH} \\
\text { measurement } \\
\text { system } \\
\text { (Auto-pH) is } \\
\text { implemented }\end{array}$ & $\begin{array}{l}\text { Current } \\
\text { measurement } \\
\text { method fails } \\
\text { to grasp the } \\
\text { rate of the } \\
\text { CO2 } \\
\text { exchange at } \\
\text { the air-water } \\
\text { interface }\end{array}$ \\
\hline 5 & $\begin{array}{l}\text { Automated } \\
\text { indoor } \\
\text { Aquaponic } \\
\text { cultivation } \\
\text { technique }\end{array}$ & $\begin{array}{l}\text { M.F. Saaid, N. } \\
\text { S. M. Fadhil, } \\
\text { M.S.A. Megat } \\
\text { Ali, M.Z.H. } \\
\text { Noor:2013 } \\
\text { IEEE }\end{array}$ & $\begin{array}{l}\text { Aquaponic } \\
\text { Cultivation } \\
\text { Technique }\end{array}$ & $\begin{array}{c}\text { System } \\
\text { designed for } \\
\text { indoor set-up } \\
\text { only. }\end{array}$ \\
\hline 6 & $\begin{array}{l}\text { Nutrient } \\
\text { Solution } \\
\text { Control } \\
\text { Network for } \\
\text { Hydroponics } \\
\text { System }\end{array}$ & $\begin{array}{c}\text { P. Hemawanit } \\
\text { AdCONIP' } \\
\text { Aug. } 2005\end{array}$ & $\begin{array}{c}\text { Nutrients } \\
\text { Solution } \\
\text { control } \\
\text { system is } \\
\text { implemented } \\
\text {. }\end{array}$ & $\begin{array}{c}\text { Plants can be } \\
\text { grown till } \\
\text { few stages } \\
\text { only. }\end{array}$ \\
\hline 7 & $\begin{array}{l}\text { Portable Device } \\
\text { for Stock } \\
\text { Identification } \\
\text { System } \\
\text { (PDSIS) }\end{array}$ & $\begin{array}{l}\text { Saaid, M.F., } \\
\text { Roslan, } \\
\text { M.Z.M., } \\
\text { Megat Ali, } \\
\text { M.S.A. : } 2014 \\
\text { IEEE }\end{array}$ & $\begin{array}{c}\text { Portable } \\
\text { devices can } \\
\text { be access } \\
\text { from } \\
\text { anywhere. }\end{array}$ & $\begin{array}{c}\text { Sometimes it } \\
\text { is difficult to } \\
\text { detect } \\
\text { portable } \\
\text { devices. }\end{array}$ \\
\hline 8 & $\begin{array}{c}\text { Intelligent Plant } \\
\text { Care } \\
\text { Hydroponic } \\
\text { Box Using } \\
\text { IoTtalk }\end{array}$ & $\begin{array}{c}\text { Tsung-Han } \\
\text { Wu, Chun-Hao } \\
\text { Chang, Yun- } \\
\text { Wei Lin, Lan- } \\
\text { Da Van, Yi- } \\
\text { Bing Lin:2016 } \\
\text { IEEE }\end{array}$ & $\begin{array}{c}\text { The } \\
\text { intelligent } \\
\text { plant care } \\
\text { hydroponic } \\
\text { box } \\
\text { (ipchbox) } \\
\text { ipch-box's } \\
\text { sensing and } \\
\text { the response } \\
\text { systems } \\
\text { used. }\end{array}$ & $\begin{array}{l}\text { Area is } \\
\text { restricted } \\
\text { And can be } \\
\text { performed } \\
\text { inside } \\
\text { IPCHbox. }\end{array}$ \\
\hline 9 & $\begin{array}{l}\text { Estimation of } \\
\text { Electrical } \\
\text { Conductivity } \\
\text { and pH in } \\
\text { Hydroponic } \\
\text { Nutrient } \\
\text { Mixing System } \\
\text { using Linear } \\
\text { Regression } \\
\text { Algorithm } \\
\end{array}$ & $\begin{array}{c}\text { Theeramet } \\
\text { Kaewwiset, } \\
\text { Thongchai } \\
\text { Yooyativong:2 } \\
\text { 017 IEEE }\end{array}$ & $\begin{array}{c}\text { EC(Electrica } \\
1 \\
\text { Conductivity } \\
\text { ) and Linear } \\
\text { Regression } \\
\text { Algorithm } \\
\text { used }\end{array}$ & $\begin{array}{l}\text { Works only } \\
\text { for few } \\
\text { Particular } \\
\text { plants. }\end{array}$ \\
\hline 10 & $\begin{array}{l}\text { Integrating } \\
\text { Scheduled } \\
\text { Hydroponic } \\
\text { System }\end{array}$ & $\begin{array}{c}\text { Dr. S. } \\
\text { Umamaheswar } \\
\text { i, A. Preethi, } \\
\text { E. Pravin, R. } \\
\text { Dhanusha : } \\
\text { 2016 IEEE }\end{array}$ & $\begin{array}{l}\text { Improvises } \\
\text { the growth } \\
\text { of crops } \\
\text { rapidly. }\end{array}$ & $\begin{array}{l}\text { Only Single } \\
\text { type of crops } \\
\text { can be used. }\end{array}$ \\
\hline
\end{tabular}

\section{PROPOSED RESEARCH}

The first module is input module which is nothing but farm with hydroponics style, another module that is water testing module is responsible for testing $\mathrm{pH}$ levels, NPK factors contained in the nutrient solution provided to the crop. Sensors are aided in identifying, understanding and utilizing information that quantifies variations in crop. The $\mathrm{pH}$ sensor ensures that the $\mathrm{pH}$ of the nutrient-rich solution stays within a specified range and will control the release of an acid and bases to adjust $\mathrm{pH}$. The hygrometer ensures that the plants are getting sufficient amounts of water and will increase watering cycles if the growing medium is dry. The task of Environmental testing module is to monitor the temperature, humidity using sensors with Raspberry Pi and using them to control various other pieces. This module is also able to examine the power failure, equipment failure. The Decision Support System module collects all the information and output generated from previous modules and it takes decision for smart farming. The farmers will able to retrieve the sensor data for live readings.

The work flow of proposed system is represented in Fig. 1 and all subsystems are discussed sequentially.

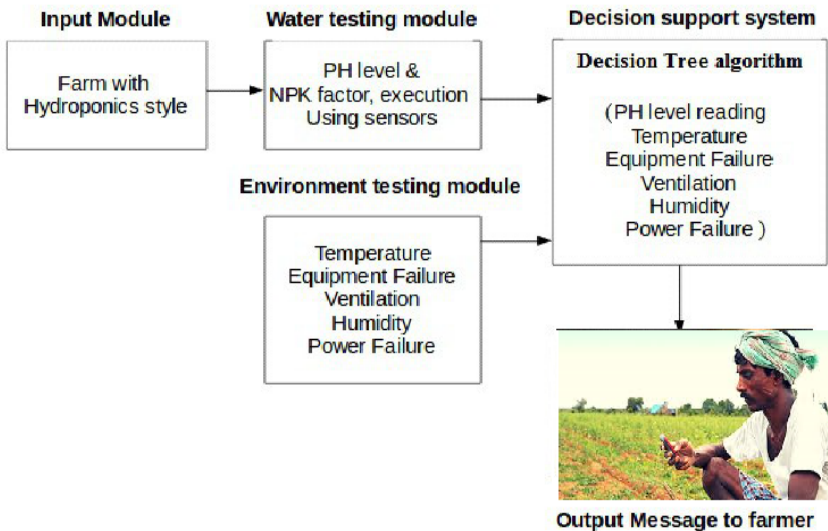

Figure 1. Work Flow of proposed research

\section{Input Module}

The input will be taken from farm with hydroponic style, for getting input from farm different types of sensors are used such as $\mathrm{pH}$ sensor, NPK sensor, humidity sensor, etc. $\mathrm{pH}$ meter and water level sensors are used for calibrating the appropriate measurements needed for the plant growth. All the water and nutrient solution are placed in a reservoir from which they are sent to the crops.

\section{Water Testing Module}

As we are using dip water culture so plant roots are dip inside the water and we are providing nutrients for the plants through water only. In water testing module we will test water level, $\mathrm{pH}$ value of water whether it is acidic or base. We are providing the content of soil such as NPK trough water only. The following table contain $\mathrm{pH}$ range for which plant response.

\section{Environment Testing Module}

In this module temperature of environment, climatic changes, humidity also detect any equipment failure or power failure.

\section{Decision Support System}

Decision support system uses decision tree algorithm for taking appropriate decisions. As we are using $\mathrm{pH}$ sensor it will take reading from water, whether water is more acidic 
or base. If water is more acidic then it will inform to user add base contents and vice-versa. Also check water level, if water level get decreases then it will inform to farmer add more water. The system will be able to take decision whether which NPK range suitable for particular plant.

\section{Mobile application}

A smart farming application that can do the job of a smart farmer to remotely monitoring crops on your farm. Based on the data from sensor, mobile application informs or notifies to farmer with the help of SMS which nutrients required for the crop, what is the temperature level, also informs about the $\mathrm{pH}$ value and which fertilizer will be provide for the plants.

\section{IMPLEMENTATION DETAILS}

The fig 2, shows system architecture. The remote monitoring system based hydroponics farming, comprises; data acquisition unit, analog to digital data conversion, an execution unit and a remote control unit.

The remote control unit is operated through mobile phone.

For experimentation of hydroponics remote monitoring system, Raspberry pi RPi3 B type, with 10/100 Ethernet RJ45 interface, the interface 40 GPI0, 4 USB2.0 slot is used which also supports Wi-Fi and Bluetooth.

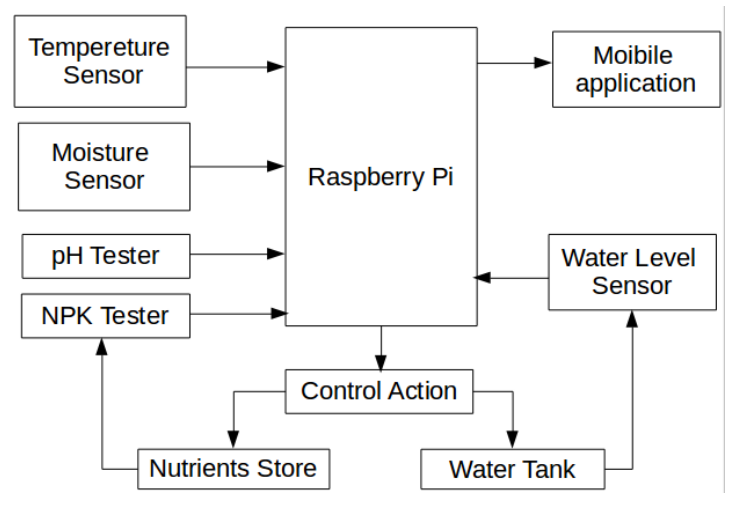

Figure 2. System Architecture

In order to send notifications to the user, the hydroponic remote monitoring system is accessed through client APP module.

The hydroponics remote monitoring system measures $\mathrm{pH}$ value of the water using $\mathrm{pH}$ sensor, NPK value of the water using NPK tester sensor and the level of water using water level sensor. These values are post-processed to the cloud via Wi-Fi, the web can refresh the current real-time data, and displays the analysis of real time data graphically.

The user can access the phone page APP through a graph view, it is possible to modify the threshold values of the dissolved NPK, and PH. When the data exceeds the threshold value, the instructions will be sent to the user.

The beneficial effects of the proposed system are utility control using wireless communication technology between the mobile phone and the remote site raspberry pi. Raspberry pi get connected to the phone and transmit the information to each other. The timely delivery and simple operations can help farmers at different times, at different locations to grasp the hydroponics water quality, surface condition, turn on or off remotely related to equipment, reduce the workload and reduce the risk.

The standard values specified here in table 2 are given as a broad range. These values should be noted that specific plant requirements may vary according to regional climatic conditions, and from season to season within that region[11].

Generally plants will have a higher nutrient requirement during cooler months and a lower requirement in the hottest months. That's why, a stronger nutrient solution should be maintained during winter, with a weaker solution during summer when plants take up and transpire more water than nutrients.

Table II. Standard Values

\begin{tabular}{|c|c|c|c|c|}
\hline Plants & $\boldsymbol{p H}$ & $\boldsymbol{C F}$ & $\boldsymbol{E C}$ & $\boldsymbol{P P M}$ \\
\hline Bean & 6.0 & $20-40$ & $2-4$ & $1400-2800$ \\
\hline Beetroot & $6.0-6.5$ & $8-50$ & $0.8-5$ & $1260-3500$ \\
\hline Broccoli & $6.0-6.5$ & $28-35$ & $2.8-3.5$ & $1960-2450$ \\
\hline Brussels Sprout & $6.5-7.5$ & $25-30$ & $2.5-3.0$ & $1750-2100$ \\
\hline Cabbage & $6.5-7.0$ & $25-30$ & $2.5-3.0$ & $1750-2100$ \\
\hline Capsicum & $6.0-6.5$ & $18-22$ & $1.8-2.2$ & $1260-1540$ \\
\hline Cauliflower & $6.0-7.0$ & $5-20$ & $0.5-2.0$ & $1050-1400$ \\
\hline Cucumber & $5.8-6.0$ & $17-25$ & $1.7-2.5$ & $1190-1750$ \\
\hline Garlic & 6.0 & $14-18$ & $1.4-1.8$ & $980-1260$ \\
\hline Lettuce & $5.5-6.5$ & $8-12$ & $0.8-1.2$ & $560-840$ \\
\hline Onions & $6.0-6.7$ & $14-18$ & $1.4-1.8$ & $980-1260$ \\
\hline Bell Peppers & $6.0-6.5$ & $20-25$ & $2.0-2.5$ & $1400-1750$ \\
\hline Potato & $5.0-6.0$ & $20-25$ & $2.0-2.5$ & $1400-1750$ \\
\hline Pumpkin & $5.5-7.5$ & $18-24$ & $1.8-2.4$ & $1260-1680$ \\
\hline Radish & $6.0-7.0$ & $16-22$ & $1.6-2.2$ & $840-1540$ \\
\hline Spinach & $5.5-6.6$ & $18-23$ & $1.8-2.3$ & $1260-1610$ \\
\hline Sweet Corn & 6.0 & $16-24$ & $1.6-2.4$ & $840-1680$ \\
\hline Sweet Potato & $5.5-6.0$ & $20-25$ & $2.0-2.5$ & $1400-1750$ \\
\hline Tomato & $5.5-6.5$ & $20-50$ & $2.0-5.0$ & $1400-3500$ \\
\hline & & & & \\
\hline
\end{tabular}

\section{CONCLUSION}

The nutrient solution used in this method plays an important role in the growth of the plants. Preparation of Nutrient Solution and recycling of the used nutrient solution and water is an important task that determines the efficiency of hydroponic farming; it consists of two variables $\mathrm{pH}$ and NPK factor. The proposed work will implement a Decision Support System for Smart farming. This is an IOT based application which addresses the issue of vegetable productivity. In addition to this, the temperature of nutrient solution also plays a vital role in delivering the nutrient content to plants. Because of this type of farming farmer will able to grow any crop in any season. By using sensors we will get proper reading of nutrient solution to take the decisions and send notification to the end users.

\section{REFERENCES}

[1] Saaid M.F., Sanuddin A., Megat Ali, M.S.A. I.M Yasin, "Automated pH Controller System for Hydroponic 
Cultivation”, 2015 IEEE International Conference on System Engineering and Technology (ICSET).

[2] Lenord Melvix J.S.M, Sridevi C., "Design of Efficient Hydroponic Nutrient Solution Control System using Soft Computing based Solution Grading”, 2014 International Conference on Computation of Power, Energy, Information and Communication, (ICCPETC).

[3] S. Fourside. Top-Fed DWC Cannabis Setup Guide Bubbleponics. Available: http://growweedeasy.com/highyieldbubbleponics-technique

[4] Saaid, M.F. Yahya, N.A.M. ; Noor, M.Z.H. ; Ali, M.S.A.M, "A development of an automatic microcontroller system for Deep Water Culture (DWC)," in Signal Processing and its Applications (CSPA), 2013 IEEE 9th International Colloquium on, 2013, pp. 328-332.

[5] G. P. Gupta, text book of PLANT DISEASES. 4831/24, Ansari road, prahlad street darjya ganj, new delhi-110002 india: Discovery Publishing House, 2004.

[6] P. Hemawanit, "Nutrient Solution Control Network for Hydroponics System," in Proc. Symp. Advanced Control of Industrial Processes ( AdCONIP’05), ed, Aug. 2005, pp. pp.104-106.
[7] S. Nakaoka and A. Yamada, "A system for measuring the photosynthetic activity of water plants based on carbon dioxide absorption," in Micro-NanoMechatronics and Human Science (MHS), 2012 International Symposium on, 2012, pp. 29-31.

[8] M. U. F. Kirschbaum. (2010, 6/4/2014). Does Enhanced Photosynthesis Enhance Growth? Lessons Learned from CO2 Enrichment Studies[W]. Available: http://www.plantphysiol.org/content/155/1/117

[9] Saaid, M.F., Fadhil, N.S.M., Ali, M.S.A.M., Noor, M.Z.H. "Automated indoor Aquaponic cultivation technique," in 2013 IEEE 3rd International Conference on System Engineering and Technology (ICSET), pp. 285 - 289.

[10] Saaid, M.F., Roslan, M.Z.M., Megat Ali, M.S.A. "Portable Device for Stock Identification System (PDSIS)," in 2014 IEEE 5th Control and System Graduate Research Colloquium (ICSGRC), , pp. $274-278$.

[11] http://www.homehydrosystems.com/ph_tds_ppm/ph_veget ables_page.html last date referred-15/01/18 